\title{
THE MODEL OF THE FAMILY AND FAMILY UPBRINGING PROPAGATED BY THE LOCAL PRESS OF THE GREATER POLAND REGION IN THE SECOND REPUBLIC OF POLAND
}

\begin{abstract}
Annotation. During the interwar period, local press played a major role in the socio-cultural life of the local communities in the Greater Poland region.

With the high number of periodicals [1], the local press had a substantial influence on the sociocultural life and education in the towns and cities of the region. It played a major educational role. It had an educational influence on the local communities, because the periodicals propagated models and forms of social and family life among them. The political and ideological stance of most of the periodicals was clearly defined as Catholic and national, therefore, the models of social activities that they promoted were consistent with this worldview. In consequence, the press propagated educational principles and ideas on upbringing, models of the family, a wifemother, a husband-father, and children compatible with Catholic Social Teaching and the ideology of National Democratic political parties (Stronnictwo Narodowe [National Party], Narodowa Demokracja [National Democracy]).
\end{abstract}

The model of the farmers' families and those of the Middle Class was consistent with the clearly defined National Democratic ideology prevalent among the members of the local communities of Greater Poland, with its deep-rooted Catholicism, and with the experiences (characteristics, qualities) that became established in the times of the Partitions of Poland.

Keywords: model of the family, Catholic family, family upbringing, model of a good wifemother, model of a husband-father, child.

Introduction: The model of the family as the reflection of the cultural character of Greater Poland region

The model of the family and family upbringing propagated in the local press of the Greater Poland region was in accordance with (consistent with) Catholic Social Teaching, in which family was considered the chief, primary, and natural environment of upbringing with its aim formulated as "a grave obligation to see to the religious and moral education of $\langle\ldots .$.$\rangle children, as well as to their physical$ and civic training, $<\ldots>$ and moreover to provide for their temporal well-being" [2].
The idea of marriage was shaped by the promoted model of upbringing. It was perceived as "a sacrament in which through a voluntary contract a man and a woman establish an indissoluble bond with bearing and rearing of offspring and mutual help in life as its objectives" [3]. The roles and obligations of the married couple were defined, as well: "it is necessary that the man who toils and labours to provide for his home and frequently returns exhausted from work is taken care of by the woman and comforted by the family. As she is weaker by nature, the woman requires a supportive guide. The husband works to provide for the home, and the woman is its guardian and master. As the husband is the head of the family, so the wife is its heart. They complement each other for mutual benefit and for earthly and eternal happiness" [4]. At the same time, the dissolubility of marriage was emphasised - this rule was protected by numerous forms and ways.

Propagated in the local Greater Poland region press the model of the family and familial upbringing

In accordance with the propagated model of upbringing in which the family was considered the chief, primary, and natural environment of upbringing <...> the Catholic model of the family was promoted in the press. It was emphasised that "the family is the best educational environment for the young generation, and rearing offspring is the natural aim of the family; furthermore, sacrifice, patience, compliance and other related social virtues are indispensible in good married life" [5]. Readers were often reminded that "parents live and work for their children, who are the only objects of their love, their care, and a source of comfort and hope" [6].

In the periodicals of Greater Poland the importance of the family (family upbringing) for the society and the country was underlined; it was states that "the state and the church are as the families are. <...> The state, the motherland look to the families, as it is in good families that brave sons are born" [7]. It was argued that in the family "a child learns to combat its selfishness, learns mortification, 
compliance, understanding, sacrifice, i.e., the virtues without which society would be nothing but a cluster of thieves and villains" [8]. It was frequently emphasised that "a Christian family provides the best preparation for social life, the only guarantee of strong states and societies $\langle\ldots . . ;$; therefore, a society requires authority to develop. In a Christian family the parents are the authority. By their instructions children must abide, and it is through obedience itself that a future citizen is formed. Since his early years he learns respect towards the parents, and later in life - towards the government" [9].

It was written that "a Christian family is the first school of love - a man living is such a family $<\ldots>$ becomes a benefactor of mankind - a real, valuable human being, with a dignifying influence on the entire society. It is on family life that a man's future depends - whether he will become a selfish individual, or a person perfectly prepared for cooperation with others. A Christian family is the first school of compliance, as all disharmony within it is excluded. A bond of blood, a community of ideals, labour, and social position - the influence of it all allows for the shaping of a healthy character" [10].

It was underlined that "in the family a child learns first the rules of moral and social life. The family constitutes the best environment of upbringing - schools, the Church, and life only build upon the foundations of family upbringing. While it is true that for parents the family life is a source of affliction and trouble connected with providing children with food and education, it is also a source of joy, satisfaction, and happiness, especially when the calm and merry family atmosphere brings delightful moments after a day of toil and labour. The more careful the upbringing of children, the greater the strength and health of the society, the safer its future" [11].

The image of a good Polish mother and housewife, with her proper roles and obligations, was repeatedly depicted in the press. It was written that "a woman ought to busy herself with cooking, washing clothes, sewing, baking, and if she lives in the country, she is to work on the farm. First and foremost, it is her duty as a housewife to keep the house clean and in order, <...> Although the home of good housewife may be poor, it is always orderly. Often a wife's slovenliness forces a husband to take his hat and run to the inn. Hard work and thriftiness are the virtues of a good housewife. The husband works with plough, axe, and shovel in the field or in a factory, and the woman with a frying pan, needle, or a brush in hand. A good housewife loves her home and her work and has no time for gossiping with her neighbours" [12].

It was explained what the housework of a mother and a wife should be, and the following pieces of advice were enumerated: "housekeeping does not consist in merely keeping things in order; members of the family and the household ought to be provided with food and clothes, and their health should be looked after. It is the great work, the great social service of the Polish mother-wife. The success in this work is dependent on numerous conditions. The first one is the skill required in housework; it needs to be acquired at home or school, or on special courses; thriftiness in housekeeping is crucial, especially in times of poverty. It consists in making skilful use of that which is required to maintain and run the house (food, firewood or coal), in purchasing only that which is indispensible and in good quality $\langle\ldots\rangle$, it is also necessary to save money, $<\ldots . .>$ living large is a deadly illness <...>. Instead of the destructive prodigality and desire of fancy clothes and the admiration of the world a good Polish mother and wife should work to lower the expenditures, but without any risk to the health. That is why a daily account is necessary, the money spent ought to be counted and what to buy tomorrow should be considered in order not to follow the first impulse, as it is often the case, and not to purchase things unneeded or even harmful. The skills such as sewing simple clothes or underwear for oneself and others allow for more savings" [13].

According to the promoted model, it was the aim of the Polish mother and wife to "take care to maintain peace", which would consist in "avoiding quarrel, avoiding the company of gossipers of both sexes, attempting to calm the anger of others, to reconcile the conflicted, to assuage the wrathful. The order in one's soul and surroundings is to be the source of peace. The man, who usually labours out of home, is not responsible of order at home. Maintaining order is the obligation of the woman exclusively. Her work is no less important than the paid labour of the man; it is necessary to keep the health of the bodies and the souls of all the family. In the home where all is in order there is an entirely different spirit, and different are the fruit of the children's upbringing, even misfortune brings not ruination. Since the earliest age a child ought to be instructed in ways orderly and clean. It needs to be taught how to wash properly, how to take good care of clothes and shoes, it should get accustomed to maintaining order at home, to following a schedule, to discipline at the table, in play and in leisure. If the mothers do so, they contribute to the revival of 
the Motherland, and they also profit themselves. When a man sees order he becomes attached to his home, he gladly spends time there and runs not to the inn, looks not for friends. <...> All the family, the children, even the youngest ones, ought to involved in keeping the place tidy. At home, as on every good farm, there needs to be a division of labour, everyone should know well what to do throughout the day and the right place for all things. That is how the home becomes a school of good, practical life. The headmaster of such school is the woman: a mother, an elder sister, a daughter" [14].

The ideal of a good Polish husband and father was also propagated in press articles. For example, in Issue 7 of the "Tygodnik Parafii Zbąszyńskiej" in 1934 the "Husbands' commandments" were published in a form resembling the Decalogue:

"1. Remember always that though you are the master of the house, you are not a tyrant.

2. Forget not that your wife is not an angel; she is a human being with its faults that you should bear with the same patience as those of your own.

3. Bear in mind that a woman is in part physically weaker than a man and it is often that only through the overcoming of the frailty of her body she is able to withstand the daily toil.

4. Though you know not the details of housekeeping, you do not have the right to disregard it. The work of a woman is only appreciated after she is gone.

5. Remember the sentence: A noble man appreciates that which he himself cannot do, and only a simpleton scorns that which he has not accomplished himself.

6. Give you wife money for housekeeping and for her own needs separately. Do not let her be alone in bearing the necessities of daily life. The greater the sacrifice, the more precious the home.

7. From time to time have a good word for your wife's skilful housekeeping and for herself. It will be a great incentive for her, though she might not admit it.

8. Be just and favour not one child over others. It hurts a mother's heart.

9. Ask your wife about the reasons for her undertakings before reprimanding her. Never reprimand her in the presence of children; when they can see you always agree with her.

10. If you have argued, remember these words: Do not let the sun settle over your wrath! Reconcile before it is too late!"

Parental obligations were often discussed in the press; it was claimed that: "a mother who loves her child shall not limit herself to taking care of its health and physical and mental development; she shall pay close attention to the religious upbringing of her infant. While to the child the mother is an embodiment of devoted and forgiving love, of a love full of humility, the father is a complement to the mother, an image of gravity, unbending will, and virility. And as the child grows, the life experience and the gravity of the father ought to be underlined in its upbringing. It is the father's duty to care for the child's upbringing in its crucial years (15-18 years of age). It is then that the father, drawing from his extensive experience, needs to become a guide for his son or daughter - to curb their youthful wantonness, to rectify their false and misleading ideas about the world and human life. Therefore, it is not only cardinal that the father and the mother communicate as to the ways of upbringing their children; they ought to agree on the what educational means to use, as well" [15].

Advice on a mother's correct attitude to and relations with her children was published quite frequently; among others, it was written that: "Some mothers are wrong in their belief that by being highly indulgent to their children they show them true, deep love, because through indulgence they, in truth, only humour themselves, while causing the worst of harms to the child. The little one will soon comprehend that by screaming he can exert his will and he will cry to get anything he desires, and such a spoiled child will be just as a man learning to play the trumpet - extremely unpleasant company. In relations with children gentleness ought to be combined with firmness. A child's liberty should not be limited with unnecessary rules. Yet, when you refuse or command something you must not change your mind. Because if a child does not learn from the very beginning that the mother's 'yes' means yes, and that her 'no' means no, it will become fastidious and stubborn and it will attempt to force you to change the demands, and you must remember that if the mother yields her gravity is undermined and ultimately lost. And the gravity of motherhood is your essential influence on the child. Whether you promise the child a smack or a biscuit, you need to keep it, because once you lose its trust you can never regain it. A mother who surrenders all her personal pleasures and who devotes all her time, strength, and every penny to her children teaches them to always expect it from her. Excessive kindness raises egoists. If a mother wears an old dress so that her idle son may have new clothes, if she toils so that her little daughter may afford a new hat, she voluntarily contributes to their idleness and egoism 
and ultimately they will ignore her. A sagacious mother does not forget that for her children she is the master of the household and that since their earliest age the children need to grow accustomed to looking up to their mother rather than looking down on her" [16].

The mother's role in the upbringing of daughters was believed to be crucial. It was written that "it is to be the aim of the mother's upbringing to have the girl grow into a brave daughter, wife, mother, housewife, citizen. Upbringing ought to prepare girls for their probable future obligations - marriage and motherhood - which constitute a woman's proper calling; it should allow them to fulfil these duties in the future. Upbringing ought to make a woman out of a girl, a woman who walks through life with strong faith, with the love of truth, goodness, and beauty, fondness of housework and social activity, and energy, and who scorns the thoughtless, idle life of a doll; the aim of the upbringing of young girls is to be their preparation for independent, practical life, $<\ldots\rangle$ they must be taught how to make life at home pleasant, enjoyable for others <...>, how to turn the house into a calm, sunny, joyful haven for the father, the brother, the husband, the son, a centre of love and happiness" [17]. "A maiden who takes care of herself, who is orderly and practical is more likely than a sloven and a scruff to find a good husband" [18].

In the articles discussing the problems of family upbringing an attempt was made to define its essence and its aims. It was written that "the upbringing of a child is often limited to the first 'stanzas' known to all by heart, i.e. to providing food and clothes, to some care for its appearance, to forms of social life, for example: how a child should behave in the presence of adults, at the table, during play or work with peers. In this case adults instruct, admonish, command and even punish for disobedience. Essentially, it is not upbringing - it is taming. <...> When we discuss the upbringing of a human being, we should take into account his body and soul. <...> If a child is to be raised properly it is not sufficient to instruct or show it what to do; it must be placed in conditions allowing it to do it all on its own, so that it may train itself to deeds, that is, to virtuous action" [19].

The duties of the parents to the children were also defined - "it is a parental obligation to raise children in such manner as to allow them to find a way of life in the world $<\ldots . .>$ to make them love work, thriftiness, order, and rectitude. If a child is brought up in such rules it will not be poor and lost in the world, even when it does not inherit an estate; certainly, the love of work, thriftiness, order, and rectitude lets one become wealthy and important easily. If you leave an inheritance, the child will not waste it on debauchery and extravagance; to the contrary, it will be spent sensibly, used to noble aims, and shared with orphans and with the poor" [20].

The press used advice and examples to shape proper attitudes of children towards their parents - "if you, the parents, want your children to approach you with respect and reverence, first demonstrate to them yourself how to fulfil the sacred duties to one's fathers. Punish your child severely whenever it insults your father and mother. Take care of your parents in their time of weakness, do not let them weep - and the beautiful example of the love of one's parents will remain deep inside the hearts of your offspring. It is, therefore, in your power to determine whether the child will respect you or not. Your child will treat you the same way you treat your parents. <...> If children are to respect their parents, so the parents are to live together in concord and humbleness, have patience in their relations, live together in peace and mutual love" [21].

The issues related to family upbringing were often discussed in the numerous local periodicals, in which there were separate columns dedicated to the problems of upbringing ("The educational section", "Mistakes in the upbringing of children", "Advice for parents", "Remarks on upbringing"). The problems of upbringing were discussed therein, educational advice was given, remarks on upbringing were made, and examples of proper and improper (as a warning) educational proceedings were quoted.

In one of the articles it was argued that "the reason for the corruption of youth, which parents deplore, lies in the parents themselves exclusively" [22]. It was written that "by observing the way sons and daughters behave one may discover what the principles that their parent adhered to were and what examples they presented to their children. Parents have always been responsible to God and society for the bad conduct of their children" [23]. The issue of punishment was also frequently addressed; it was claimed that: "children raised in discipline, in fear of God will be the pride of their parents, rather than those mollycoddled. Let there be agreement between the mother and the father and harmony in the upbringing of children, so that the mother does not have to forbid what the father allows and vice versa" [24]. "Parents should be careful not to lose gravity and majesty in their children's eyes" [25]. "If necessity arises to punish children for their pranks and bad conduct, let the punishment be born of parental love rather than vehemence or anger. In rearing children it is indispensible to combine gentleness and firmness". 


\section{Conclusions}

The majority of the articles on upbringing published in the local press was of a didactic, ideological, moralising character - they were the means of the realisation of clearly defined aims of the "spiritual authority" (the hierarchy of the Church) and the "political authority". The idea was to form proper attitudes and to propagate certain models of the family and of family life. Some of the articles are quite tactless, immoderate, and subjective; in a number of publications the models of the family and of family upbringing inconsistent with the Catholic and national ones were severely criticised. Despite this partiality in the approach to the problems of upbringing the local periodicals enjoyed great popularity and recognition among the local communities of Greater Poland. The presented stance on the issues connected with upbringing was in accord with the strong political and moral (religious) ideas of the population; it was simply a reflection of the worldview dominant among the people and it is certain that in the local communities it fulfilled the role of an educational factor and that it contributed to the forming of the specific cultural character (image) of Greater Poland in the interwar period and to the education of its inhabitants.

\section{References}

1. In 1919 there were 38 periodicals published in the Poznań Voivodship, in 1922 - 40, 1923 - 23, 1924 - 50, 1925 - 66, $1927-86,1928$ - 105, 1931 - 101, 1932 - 102, 1933 - 80, 1934 - 71, 1935 - 81, 1936 - 93, 1937 - 101. In 193931 localities (Poznań excluded) had their own press (in which 72 periodicals in Polish and 10 periodicals in German and Yiddish were published). In 1929 there were 112 local periodicals published in the Poznań Voivodship, among them: "Orędownik Gostyński”, "Ziemia Gostyńska”, "Gazeta Gostyńska", "Gazeta Leszczyńska", "Wici Wielkopolskie" in Września, "Kurier Poznański", "Orędownik Grodziski", "Gazeta Ostrowska”, "Gazeta Szamotulska", "Gazeta Ostrzeszowska", "Kurier Czarnkowski", "Goniec Krotoszyński", "Gazeta Wagrowiecka", "Głos Śmigielski”, "Dziennik Rawicki”, "Głos Średzki”.

2. "Divini Illius Magistri" - encyclical of Pius XI.

3. "Wiadomości Parafialne. Pisemko Tygodniowe Parafii Farnej św. Małgorzaty w Gostyniu", Issue 4/1939, p.4.

4. “Orędownik Gostyński”, Issue 8/1936, p.3.
5. “Tygodnik Parafji Zbąszyńskiej”, Issue 2/1931, p. 2 (article titled "Catholic family"). The model of a Catholic family was also presented in the articles: "The holiest of families" "TPZ" Issue 1/1934, p.1), "Winter evenings in the family" ("TPZ" Issue 50/1932, p.2), "The foundation of the state" ("TPZ" Issue 2/1936, pp.1-2), "On family. The presentation made on the sacred day of the Holy Family", a series of three articles by R. Różański on the model of upbringing in a Catholic family ("TPZ" Issue 13/1938, p.3, Issue 14/1938, p.4, Issue 15/1938, pp.5-6).

6. “Gazeta Leszczyńska”, Issue 12/1932, p.4.

7. "Tygodnik Parafialny Parafii Wszystkich Świętych", Issue 5/1934, p.2.

8. “Orędownik Gostyński”, Issue 2/1933, p.4.

9. "Gazeta Gostyńska”, Issue 6/1932, p.3.

10. “Tygodnik Parafji Zbąszyńskiej”, Issue 2/1936, pp.1-2.

11. "Gazeta Leszczyńska”, Issue 9/1929, p.3.

12. “Tygodnik Parafji Zbaszyńskiej”, Issue 11/1933, pp.2-3; Issue 12/1933, p.3 (article titled "Woman as a guardian of the family home"); Also the articles: "Important for young mothers. Taking care of the health of the mother and the child" ("TPZ" Issue 51/1932, p.3); "What to remember before the wedding?" "“TPZ" Issue 3/1933, p.1-2); "Maternal upbringing" ("TPZ" Issue $1 / 1934$, p.2).

13. "Tygodnik Parafji Zbąszyńskiej”, Issue 11/1932, pp.2-3 (article titled: "A Polish woman as a good housewife").

14. "Tygodnik Parafji Zbąszyńskiej”, nr 10/1932, p.2-3 (article titled: "A Polish woman as an apostle of faith and peace").

15. "Tygodnik Parafii Szmotulskiej:, Issue 3/1937, p. 2 .

16. "Tygodnik Katolicki dla Rogoźna i Okolic", Issue 3/1936, p.3.

17. "Tygodnik Parafji Zbąszyńskiej”, Issue 25/1931, pp.7-8 (article titled: "A few remarks on the upbringing of youth, especially girls" by S.Stopow).

18. "Tygodnik Parafji Zbaszyńskiej”, Issue 10/1932, pp.2-3 (article titled: "A Polish woman as an apostle of faith and peace").

19. "Gazeta Gostyńska", Issue 4/1934, p.4.

20. “Orędownik Gostyński”, Issue 7/1934, p.4.

21. "Tygodnik Parafialny Parafii Wszystkich Świętych", Issue 3/1938, p.3.

22. "Wiadomości Parafialne. Pisemko Tygodniowe Parafii Farnej św. Małgorzaty w Gostyniu", Issue $4 / 1930$, p.2. 
23. “Tygodnik Parafji Zbąszyńskiej”, Issue 1/1936, p.3 (article titled "The educational section. Remarks on the upbringing of children. Children are bad! Whose fault is it?").

24. “Tygodnik Parafji Szamotulskiej”, Issue 5/1938, p.2.

25. "Ziemia Gostyńska", Issue 2/1926, p.7.

26. “Tygodnik Katolicki dla Rogoźna i Okolic”, nr 5/1936, p.2.

\section{Summary}

\section{Mirosław Piwowarczyk}

\section{THE MODEL OF THE FAMILY AND FAMILY UPBRINGING PROPAGATED BY THE LOCAL PRESS OF THE GREATER POLAND REGION IN THE SECOND REPUBLIC OF POLAND}

In the Second Republic of Poland, local press played a major role in fulfilling the needs of the government administration, the local government, and political parties as well as the expectations of broad social circles, groups, and local communities; it addressed social needs and expectations by providing information about social, political, cultural, educational, moral, and economic life of the particular social groups. It constituted a means of propaganda and political agitation; it served to popularise the ideologies of political parties and it expressed the worldviews of particular local communities; its place in the regional economic life was important; its influence was pedagogical, and it took an active part in propagating education and promoting an interest in the region.

It was a reflection of social relations and political and national divisions as well as an initiator of numerous cultural events. It recorded the image of the life of the inhabitants of cities and their surroundings. Its educational influence on the young generation consisted in suggesting models and forms of social activity, promoting certain ideologies, ideas on upbringing, models of behaviour, and forming and determining the attitudes and the activity of the local communities. Its role in Greater Poland (with the clearly defined ideological and cultural character of the region) was remarkable, because there the local press was essential in creating sociocultural life in small towns and in educating their inhabitants. The local press belonged to the group of periodicals that had a major educational influence and which determined the cultural character of small communities.

In a number of cases the local periodicals served as official publications of local communities. They were a source of information on the life of the region and the town with its surroundings, they constituted a chronicle of local events, and they propagated a certain worldview and ideas on upbringing consistent with it.

The local press had a substantial role in the education and upbringing in the community. It promoted a uniform, clearly defined stance (idea) of upbringing, typically in accordance with the Catholic Social Teaching and the ideology of National Democratic parties.

The problems of social, civil, religious, moral, and family character were frequently discussed in the columns of the local press, "in the Catholic and national spirit". The periodicals would firmly propagate the Catholic family model, certain principles of family life, and models of the family, upbringing, a wife-mother, a husband-father, children as well as the models of a good Polish woman, a mother, and a housewife, and the ideal of a good Polish man, a husband and a father, with their respective roles and duties. The obligations of parents to their children were also defined.

Advice related to proper attitude (relation) of a mother to their children was quite often published in the columns of the local periodicals. An attempt was made at forming proper attitudes of children towards their parents by providing examples and advice. There was a number of articles emphasising the meaning and importance of the combined effort of families and schools in education and upbringing for the good of children. Thus, local press played an educational role in local communities and it contributed to the forming of a specific cultural character (image) of Greater Poland in the interwar period and to the education of its inhabitants.

University of Wroclaw Institute of Pedagogy 